\title{
DESENTRALISASI, KORUPSI, DAN TAMBAL SULAM PEMERINTAHAN DAERAH DI INDONESIA
}

\author{
Ichwani Siti Utami \\ Fakultas Keguruan dan Ilmu Pendidikan, Universitas Pamulang \\ amiutami10@gmail.com \\ Naskah diterima: 8 Maret 2018, review: 13 Maret 2018, revisi: 16 Maret 2018, \\ disetujui: 23 Maret 2018.
}

\begin{abstract}
Abstrak
Artikel ini membahas secara umum tentang korupsi yang terjadi pada era desentralisasi di Indonesia. Pembahasan dalam artikel ini meliputi; kemunculan desentralisasi, tren korupsi di daerah, dan tambal sulam pemerintahan daerah. Tindak pidana korupsi yang terjadi di daerah menjadikan cita-cita demokrasi dalam menjalankan pemerintahan daerah yang bebas dari kolusi, korupsi, dan nepotisme sulit untuk terwujud. Perubahan regulasi hanya menjadi tambal sulam berjalannya otonomi daerah, belum ada kesadaran dari para pejabat atau calon pejabat daerah yang sungguh-sungguh dalam menjalankan pemerintahan daerah. Hal ini membuat rakyat daerah menjadi semakin pasif terhadap demokrasi karena dijejali berita-berita korupsi yang terjadi di daerah.
\end{abstract}

Kata-kata kunci: korupsi, desentralisasi, pemerintahan daerah

\author{
Jurnal Pendidikan Kewarganegaraan \\ Journal of Civics and Education Studies \\ The journal is published by Department of Civic Education \\ Faculty of Teacher Training and Education \\ Universitas Pamulang - Indonesia
}

Copyright (C) 2018 / ISSN: 2302-0865 


\section{PENDAHULUAN}

Berdasarkan Pasal 1 Ayat (1) UndangUndang Dasar (UUD) Republik Indonesia tahun 1945 ditentukan bahwa "Negara Indonesia ialah negara kesatuan yang berbentuk republik." Ketentuan pada pasal tersebut merupakan suatu kenyataan bahwa para pendiri negara ini telah menentukan pilihan bahwa negara Indonesia yang diproklamasikan pada tanggal 17 Agustus 1945 adalah negara kesatuan. Pilihan pendiri negara atas bentuk negara kesatuan, membawa konsekuensi bahwa Indonesia tidak mempunyai daerah di dalam lingkungannya. Pemerintah pusat adalah satu-satunya pemegang kekuasaan pemerintahan.

Mengenai pemerintahan yang terjadi di Indonesia selama berpuluh tahun sebelum era Reformasi tahun 1998, bangsa Indonesia sering lebih familiar dengan kata government yang berarti pemerintah atau pemerintahan dari pada governance yang sesungguhnya berarti juga pemerintah atau pemerintahan (Andayani, 2012:343). Perbedaannya adalah nuansa politik yang monolitik sentralistik, maka government merupakan merupakan pemerintahan yang bertumpu pada otoritas yang menunjukan pengelolaan kewenangan tertinggi, sehingga yang terjadi adalah pemerintahan yang sentralistik, terpusat pada kekuasaan pemerintahan terpusat.

G. H Addink (2003: 9) mengatakan bahwa konsep good governance dalam konteks pemerintahan adalah dalam rangka interaksi suatu Pemerintah dan bangsanya. Maka dalam hal ini untuk menjalankan good governance berserta government, perlu adanya suatu konsep yang mampu mendobrak model pemerintahan yang sentralistik, terpusatnya suatu pemerintahan menyebabkan program-progam yang diselenggarakan Pemerintah sering kali tidak sesuai dengan kebutuhan dan permintaan masyarakat yang berada jauh di luar Pemerintah.

Hari ini, di Indonesia melalui semangat Reformasi telah menerapkan konsep yang dinamakan "desentralisasi" sebagaian para pemangku jabatan telah sadar bahwa pemerintahan yang monilistik sentralis telah menimbulkan keotoriteran. Semangat ini tertuang dalam kerangka desentralisasi sebagaimana telah diatur dalam paket Undang-undang No. 32 Tahun 2004 (amandemen Undangundang No. 22 Tahun 1999 tentang Pemerintahan Daerah) dan Undangundang No. 33 Tahun 2004 tentang Perimbangan Keuangan Pusa-Daerah (diamandemen dari Undang-undang No. 25 Tahun 1999).

Dari paket kebijakan di atas munculah istilah otonomi daerah, secara sederhana dapat diartikan sebagai hak untuk mengatur dan mengurus rumah tangga sendiri oleh satuan organisasi pemerintah di daerah. Otonomi daerah yang diberikan pemerintah pusat kepada pemerintah. Dengan demikian berdasarkan prinsip otonomi tersebut, maka ada keharusan dari pemerintah pusat untuk menyerahkan sebagaian hak dan kewenangannya daerah dalam mengatur dan mengurus rumah tangganya sendiri tanpa campur tangan atau intervensi dari 
pihak lain termasuk pemerintah pusat. Otonomi daerah dapat diartikan sebagai hak, wewenang dan kewajiban daerah untuk mengatur dan mengurus rumah tangga daerah atas inisiatif atau prakarsa sendiri tanpa instruksi pemerintah pusat.

Dengan pemberian otonomi daerah secara penuh maka masyarakat masyarakat akan lebih diberdayakan, sehingga mereka akan berpartisipasi secara aktif dalam proses pengambilan keputusan yang dibuat oleh pemerintah (Hernan, 2011: 97). Namun beberapa tahun terakhir, justru dengan dilaksanakannya disentralisasi dalam otonomi daerah, terjadi juga desentralisasi korupsi, ini terlihat sebagaimana Komisi Pemberantasa Korupsi (KPK) mencatat dari awal tahun dilaksanakannya otonomi daerah hingga tahun 2015 terdapat 64 kasus korupsi yang melibatkan 51 kepala daerah. Besarnya angka tersebut tidak hanya dapat dilihat dari satu sisi saja, terdapat pula permasalahan lain yang sebenarnya menjadi faktor terjadinya kasus korupsi yang melibatkan para kepada daerah.

Putera (2012: 163) mencatat dari naskah akademik Rancangan UndangUndang tentang Pemerintahan Daerah, bahwa secara umum desentralisasi dan otonomi daerah mampu mendorong munculnya berbagai inovasi, tetapi desentralisasi juga melahirkan banyak masalah baru dalam penyelenggaraan pemerintahan di daerah. Pada sisi lain, Hidayat (2003: 78) mencatat bahwa kebijakan desentralisasi tidak luput dari serangkaian permasalahan seperti munculnya pembengkakan organisasi daerah, terjadinya oligarki politik oleh elit lokal maupun gejala pembangkangan daerah terhadap pemerintah pusat adalah sebagian diantaranya.

Berdasarkan uraian tersebut dan sejumlah fenomena yang terjadi maka tulisan ini bertujuan untuk mengulas dan menganalisis terjadinya pesebaran korupsi yang menjangkit para kepala daerah, kemunculan Undang-Undang Otonomi Daerah justru melahirkan para elit lokal yang menguasai konstelasi politik dan berpotensi besar untuk melanggar Undang-Undang, yang mana pelanggaran terhadap Undang-Undang semakin disiasati melalui praktik-praktik politik dalam ruang demokrasi di tingkat daerah.

\section{METODE PENULISAN}

Penulisan artikel menggunakan metode studi pustaka menggunakan teknik analisis secara deskriptif untuk melihat secara mendalam mengenai kemunculan desentrasilasi dan tren korupsi dalam kaitannya dengan implementasi Undang-Undang Otonomi Daerah.

Analisis dikaitkan pada praktik pelanggaran Undang-Undang Otonomi Daerah terkait fenomena banyaknya keterlibat kepala daerah dalam kasus korupsi.

\section{PEMBAHASAN}

\section{Kemunculan Desentralisasi di Indonesia}

Sepanjang era Orde Baru berkembang dua sifat pemerintahan, yaitu sentralistik dan otokratik. Kedua ciri pemerintahan ini saling memperkuat satu sama lain, dan 
pada dasarnya tidak disukai masyarakat. Menurut Noor (2012: 54) hal tersebut karena kedua sistem itu membuat penanganan jalannya pemerintahan lebih tergantung pada pejabat daripada sistemnya. Setelah suasana itu berlangsung lebih dari tiga dekade, akhirnya pada pertengahan 1998 lahir gerakan reformasi yang dengan cepat dapat mengubah sifat pemerintahan otokratik mengarah ke sifat yang lebih demokratik. Lain halnya dengan sistem sentralisasi yang dalam usaha mengubahnya ke sistem desentralisasi agaknya memerlukan langkah-langkah terencana dalam kurun waktu panjang. Jadi, sejak runtuhnya Orde Baru yang sentralistik dan otoriter dan dimulainya era reformasi, bangsa Indonesia tengah menjalankan upaya desentralisasi yang paling cepat dan massif yang pernah ada dalam sejarah, dan gerakan desentralisasi ini dimotori oleh kekuatan-kekuatan politik regional yang muncul sejak jatuhnya pemerintahan Suharto.

Walaupun besar dan beragam, Indonesia pada waktu itu memiliki sistem administrasi dan fiskal yang sangat sentralistik. Dalam fiskal 1999 (Noor, 2012: 59), misalnya, pemerintah pusat mengumpulkan 94 persen dari pendapatan pemerintah secara umum dan sekitar 60 persen dari pengeluaran daerah dibiayai oleh transfer dari pusat. Sistem ini memperlemah hubungan antara permintaan lokal dan pengambilan keputusan dalam hal pelayanan publik lokal, mengurangi akuntabilitas lokal, dan membuat alokasi yang bersifat adhoc dari sumberdaya fiskal di seluruh daerah.
Tentu saja dengan sifat yang sentralistik dan otokratik ini, membuat ketidakpuasan dari daerah, apalagi pada saat daerah memiliki sumber daya yang melimpah namun pembangunan di daerah justru tertinggal. Eksploitasi sumber daya alam dan energi yang ada di daerah dilakukan secara terpusat oleh pemerintah pusat, sedangkan timbal balik pemerintah pusat kepada daerah tersebut sangatlah kurang dan bahkan terabaikan, sehingga tentu saja hal ini memunculkan berbagai ketidakpuasan dan bahkan ketidakpercayaan kepada pemerintah pusat (Noor, 2012: 60).

Lebih jauh lagi, istilah desentralisasi telah dikemukakan dalam rapat Panitia Persiapan Kemerdekaan Indonesia (PPKI). Gie (1968a) dalam Noor (2012:58) menuliskan bahwa istilah tersebut muncul dalam rancangan Moh. Yamin yang menyebutkan bahwa Negara Rakyat Indonesia menjalankan pembagian pekerjaan negara atas dasar desentralisasi atau dekonsentrasi yang tidak mengenal federalisme atau perpecahan negara. Moh. Yamin membagi pemerintahan menjadi pemerintahan atasan untuk pusat dan pemerintahan bawahan untuk desa atau setingkatnya.

Sedangkan di tengah tengah pemerintahan atasan dan bawahan tersebut adalah pemerintah tengahan. Kemudian konsep ini disempurnakan oleh Soepomo dalam rapat PPKI tanggal 18 Agustus 1945 yang menyatakan bahwa di bawah Pemerintah Pusat ada Pemerintahan Daerah. Sedangkan Pemerintah Daerah disusun dalam undang-undang. Di samping itu, negara 
juga menghormati kedudukan daerahdaerah yang mempunyai susunan asli yang disebut sebagai Daerah Istimewa, seperti Daerah Istimewa Yogyakarta (Noor, 2012: 61).

Pada dasarnya desentralisasi beserta kemunculannya di Indonesia merupakan suatu hal yang dapat dikatakan "penting" bagi berjalannya suatu pemerintahan, jika kemunculan istilah desentralisasi pada era kemerdekaan-sebagaimana diungkapkan oleh Moh. Yamin dalam sidang PPKI yang menekankan agar pembagian pekerjaan Pemerintahan berjalan secara merata dan tetap dalam bentuk Negara Kesatuan. Sedangkan pasca reformasi desentralisasi diterapkan sebagai sebuah konsep untuk menanggulangi otoritarianisme yang diterapkan oleh rezim Orde Baru.

Sadar atau tidak sesungguhnya pertumbuhan otonomi daerah di Indonesia sejak masa kemerdekaan sampai sekarang (masa reformasi) telah mengalami perubahan-perubahan secara fluktuatif (naik-turun) sesuai dengan realitas di lapangan yang dilalui dengan rezim pemerintahan yang berganti-ganti (Kustiawan, 2011: 312). Melihat pertumbuhan dan perkembangannya ternyata berlangsung tidak sesuai apa yang diinginkan para pendiri republik ini.

Tentu, tidaklah mengherankan bila Prof. Bagir Manan (2004: 28) mengatakan bahwa "dalam tataran pelaksanaan otonomi daerah belum pernah dilaksanakan sebagimana mestinya" Menurut Manan dalam Kustiawan (2011: 313), pemerintahan pusat dan legislatif tetap gamang dan tidak tulus hati dalam merumuskan dan menjalankan arti otonomi yang sesungguhnya dengan berbagai alasan pembenaran.

Peraturan perundang-undangan tentang pemerintahan daerah sudah mengalami perubahan sebanyak 10 (sepuluh) kali, sejak Undang-Undang (UU) Nomor 1 Tahun 1945 hingga UU Nomor 9 Tahun 2015, hanya dalam rentang waktu 65 tahun menunjukan permasalahan otonomi daerah, mulai dari UU Nomor 1 tahun 1945, UU Nomor 22 Tahun 1948, UU Nomor 1 Tahun 1957, Penetapan Presiden Nomor 6 Tahun 1959, UU Nomor 18 Tahun 1965, UU Nomor 5 Tahun 1974, UU Nomor 22 Tahun 1999, UU Nomor 32 Tahun 2004, UU Nomor 23 Tahun 2014, UU Nomor 9 Tahun 2015.

Dalam setiap perubahan, segala aspek dan penekanan-penekanan baru dalam Undang-Undang ini telah dituangkan agar terwujudnya pemerintahan daerah yang bebas dari kolusi, korupsi, dan nepotisme. Namun pada praktiknya; semangat dalam menjalankan pemerintahan daerah yang bersih dan bebas dari korupsi justru semakin melemah. Pasal 1 Butir 7 UU No. 32 Tahun 2004 tentang Pemerintahan Daerah dijelaskan bahwa "Desentralisasi merupakan Penyerahan wewenang pemerintahan oleh Pemerintah kepada daerah otonomi untuk mengatur dan mengurus urusan pemerintahan dalam sistem Negara Kesatuan Republik Indonesia".

Bila ditinjau dari perspektif ilmu politik, sesungguhnya desentralisasi seringkali diartikan sebagai "transference of authority, legislative, judicial or administrative, from a higher level of government to a lower 
level" atau devolusi kekuasaan dari pemerintahan pusat ke pemerintahan lokal. Namun tidak semua bentuk desentralisasi adalah demokratis (Kustiawan, 2011: 314). Ini terlihat dalam masa pemerintahan Orde Baru, pada masa pemerintahannya aparat pemerintah lebih berprilaku memerintah daripada melayani public (Noor, 2012: 66). Birokrasi menjadi alat bagi pemerintah untuk mengontrol sikap kritis rakyat.

\section{Tren Korupsi di Daerah}

Divisi Investigas

Indonesia Corruption Watch (ICW) dalam penelitiannya tentang Tren Korupsi Semester 1 Tahun 2014; Korupsi Daerah Makin Mengakhawatirkan mencatat bahwa berdasarkan modus, yaitu penggelapan, penyalahgunaan anggaran, dan laporan fiktif.

Tabel 1. Modus Korupsi Berdasarkan Wilayah Tahun 2014 Semester 1

\begin{tabular}{lll}
\hline Wilayah & Modus & Jumlah \\
\hline Kabupaten & Penggelapan & 51 Kasus Korupsi \\
Kota & Penyalahgunaan Anggaran & 19 Kasus Korupsi \\
Provinsi & Laporan Fiktif & 4 Kasus Korupsi \\
Pusat & Penyalahgunaan Anggaran & 4 Kasus Korupsi
\end{tabular}

Sumber: Hasil Penelitian Divisi Investigasi ICW

Wilayah Kabupaten menempati jumlah terbanyak dari Kota, Porvinsi, dan Pusat, sebanyak 51 Kasus Korupsi. Isra (2009) dalam Putera (2012: 165) memberi catatan mengenai administrasi daerah dan hubungannya dengan tumbuh berkembangannya korupsi. Pertama, program otonomi daerah tidak diikuti dengan program demokratisasi yang membuka peluang keterlibatan masyarakat dalam pemerintahan di daerah. Karenanya, program desentralisasi ini hanya memberi peluang kepada elit lokal untuk mengakses sumber-sumber ekonomi dan politik daerah, yang rawan terhadap korupsi atau penyalahgunaan wewenang. Kedua, program otonomi daerah telah memotong hirarki pemerintahan, sehingga tidak efektif lagi kontrol pemerintah pusat ke daerah karena tidak ada lagi hubungan struktural secara langsung memaksakan kepatuhan pemerintah daerah kepada pemerintah pusat. Ketiga, masyarakat belum mampu mengawasi ketika kolusi terjadi antara pihak eksekutif dengan legislatif.

Semangat desentralisasi yang tidak diimbangi dengan pola-pola prilaku pemerintah yang siap menjalankan amanah juga menjadi faktor kuat terjadinya korupsi di daerah, ICW mencatat pada tahun 2004 terdapat 432 Kasus Korupsi di berbagai daerah dengan bermacam aktor, modus, dan tingkat kerugian yang di derita oleh Negara. 
Begitupun beberapa tahun 2011 mencatat Tindak Pidana Korupsi sebelumnya Komisi Pemberantasan berdasarkan tingkat jabatan dari tahun Korupsi (KPK) dalam Laporan Tahun 2004-2011:

Tabel 2. Perkara Tindak Pidana Korupsi Tahun 2004 - 2011 Bedasarkan Tingkat Jabatan

\begin{tabular}{|c|c|c|c|c|c|c|c|c|c|}
\hline Jabatan & 2004 & 2005 & 2006 & 2007 & 2008 & 2009 & 2010 & 2011 & Jumlah \\
\hline $\begin{array}{l}\text { Anggota DPR dan } \\
\text { DPRD }\end{array}$ & - & & - & 2 & 7 & 8 & 27 & 5 & 49 \\
\hline $\begin{array}{l}\text { Kepala Lembaga } \\
\text { dan Kementrian }\end{array}$ & - & 1 & 1 & - & 1 & 1 & 2 & - & 6 \\
\hline Duta Besar & - & & - & 2 & 1 & - & 1 & - & 4 \\
\hline Komisioner & - & 3 & 2 & 1 & 1 & - & - & - & 7 \\
\hline Gubernur & 1 & & 2 & - & 2 & 2 & 1 & - & 8 \\
\hline $\begin{array}{l}\text { Wali Kota/Bupati } \\
\text { dan Wakil }\end{array}$ & - & & 3 & 7 & 5 & 5 & 4 & 5 & 29 \\
\hline Eselon I, II, dan III & 2 & 9 & 15 & 10 & 22 & 14 & 12 & 7 & 91 \\
\hline Hakim & - & & - & - & - & - & 1 & 3 & 4 \\
\hline Swasta & 1 & 4 & 5 & 3 & 12 & 11 & 8 & 11 & 55 \\
\hline Lain-lain & - & 6 & 1 & 2 & 4 & 4 & 9 & 5 & 31 \\
\hline Jumlah & 4 & 23 & 29 & 27 & 55 & 45 & 65 & 36 & 284 \\
\hline
\end{tabular}

Sumber: Laporan Tahunan KPK 2011

Dari catatan tersebut mulai dari 2004

- 2011 KPK telah menyelesaikan 284 Kasus Korupsi termasuk di tingkat daerah, jika dibandingkan dengan tabel 1.
Kemudian Hasil Penelitian Divisi Investigasi ICW juga mencatat Korupsi Berdasarkan Instansi, sebagai berikut: 
Tabel 3. Jumlah Korupsi Bedasarkan Instansi ICW Tahun 2013 - Semester 12014

\begin{tabular}{|c|c|c|c|c|c|}
\hline No. & Instanti & $\begin{array}{l}\text { Jumlah } \\
\text { Tindakan } \\
\text { Korupsi }\end{array}$ & No. & Instansi & $\begin{array}{l}\text { Jumlah } \\
\text { Tindakan } \\
\text { Korupsi }\end{array}$ \\
\hline 1 & Dirjen Pajak & 1 & 14 & $\begin{array}{l}\text { Badan Non } \\
\text { Pemerintahan }\end{array}$ & 7 \\
\hline 2 & Komisi Yudisial & 1 & 15 & $\begin{array}{l}\text { Dinas Kelautan dan } \\
\text { Perikanan }\end{array}$ & 8 \\
\hline 3 & Bank & 2 & 16 & Dinas Kesehatan & 8 \\
\hline 4 & Koperasi & 2 & 17 & Dishubkominfo & 9 \\
\hline 5 & $\begin{array}{l}\text { Dinas Pendapatan } \\
\text { Daerah }\end{array}$ & 3 & 18 & Instansi Pendidikan & 13 \\
\hline 6 & $\begin{array}{l}\text { Dinas Perdagangan } \\
\text { dan Perindustrian }\end{array}$ & 3 & 19 & BUMN & 13 \\
\hline 7 & PNPM & 3 & 20 & Dinas ESDM & 14 \\
\hline 8 & Bappeda & 4 & 21 & Badan Pemerintahan & 18 \\
\hline 9 & BUMD & 4 & 22 & Dinas Pendidikan & 19 \\
\hline 10 & $\begin{array}{l}\text { Dinsos, Transmigran, } \\
\text { dan Tenaga Kerja }\end{array}$ & 4 & 23 & Kementerian & 19 \\
\hline 11 & Penegak Hukum & 4 & 24 & $\begin{array}{l}\text { Dinas Pekerjaan } \\
\text { Umum }\end{array}$ & 20 \\
\hline 12 & Instansi Kesehatan & 5 & 25 & DPRD & 21 \\
\hline 13 & Dinas (lain-lain) & 6 & 26 & $\begin{array}{l}\text { Pemerintahan } \\
\text { Daerah }\end{array}$ & 97 \\
\hline
\end{tabular}

Sumber: Hasil Penelitian Divisi Investigasi ICW Tahun 2014

Kemudian hasil penelitian Divisi wilayah dan modus di Kabupaten, Kota, Investigasi ICW juga mencatat tentang Provinsi, dan Pusat, sebagai berikut: jumlah kasus korupsi berdasarkan 
Tabel 4. Jumlah Kasus Berdasarkan Wilayah dan Modus Tahun 2013 - Semester 12014

\begin{tabular}{lcccccccccc}
\hline Wilayah & $\mathbf{1}$ & $\mathbf{2}$ & $\mathbf{3}$ & $\mathbf{4}$ & $\mathbf{5}$ & $\mathbf{6}$ & $\mathbf{7}$ & $\mathbf{8}$ & $\mathbf{9}$ & $\mathbf{1 0}$ \\
\hline Kabupaten & 16 & 51 & 47 & 45 & 7 & 11 & 12 & 11 & 0 & 5 \\
Kota & 10 & 17 & 13 & 19 & 1 & 4 & 5 & 1 & 1 & 2 \\
Provinsi & 2 & 3 & 4 & 4 & 1 & 0 & 2 & 0 & 0 & 0 \\
Pusat & 2 & 0 & 2 & 3 & 1 & 0 & 1 & 0 & 0 & 0 \\
\hline
\end{tabular}

Keterangan: 1) Mark-up; 2) Penggelapan; 3) Laporan Fiktif; 4) Penyelahgunaan Anggaran; 5) Suap Gratifikasi; 6) Pemotongan Anggaran; 7) Penyalahgunaan Wewenang; 8) Kegiatan/Proyek Fiktif; 9) Anggaran Ganda; 10) Pungutan Liar.

Jika kita lihat perbadingan data diatas, sejak tahun 2004 hingga semester 12014 terdapat beragam modus dan keterlibatan pemerintahan daerah dalam kasus korupsi, jika kita lihat tren korupsi semakin menjadi-jadi dalam konstelasi politik, birokrasi pemerintahan, dan perumusan kebijakan. Kasus korupsi di daerah semakin mengkhawatirkan pada wilayah Pemerintahan Daerah dan Legislatif daerah.

Jika dilihat berdasarkan sektor, aktor, instansi maupun wilayah penanganan kasus. Data diatas juga menunjukan bagaimana desentralisasi korupsi terjadi dari tiap tingkatan pemerintahan daerah, menurunnya tindak pidana korupsi di tingkat pusat justru menambah jumlah deretan kasus yang terdapat di tingkat daerah, mulai dari provinsi hingga kabupaten/kota.

Jumlah kepala daerah yang menjadi tersangka meningkat lebih dari $2 x$ lipat. Pada semester 1 tahun 2013, sekurangnya tercatat 11 kepala jadi tersangka. Sedangkan pada semester 1 tahun 2014, sekurangnya tercatat 25 kepala daerah menjadi tersangka (ICW, 2014: 23).
Dengan dilaksanakannya Otonomi daerah beserta beberapa kali perupahan terhadap regulasinya, tidak sesuai dengan harapan dicita-citakan, justru korupsi semakin menjalar di pemerintahan daerah.

\section{Undang-Undang Nomor 9 Tahun 2015: Tambal Sulam dalam Pemerintahan Daerah}

Akibat banyaknya Kepala Daerah yang terjerat kasus tindak pidana korupsi, secara langsung juga mengganggu berjalannya roda pemerintahan daerah. DPR RI menganggap perlu untuk melakukan perubahan karena kondisikondisi tersebut. Undang-Undang Nomor 9 Tahun 2015 merupakan perubahan dari Undang-Undang Nomor 23 Tahun 2014 Tentang Pemerintahan Daerah. Dalam UU No 9 Tahun 2015 terdapat 6 pasal yang mengalami perubahan.

Pada bagian menimbang UU No 9 Tahun 2015 huruf a menyebutkan bahwa "bahwa untuk kesinambungan kepemimpinan di provinsi, kabupaten/kota diperlukan mekanisme peralihan kepemimpinan daerah di masa jabatannya yang demokratis untuk dapat menjamin pembangunan dan pelayanan kepada masyarakat;" huruf b menyebutkan bahwa 
"bahwa ketentuan tugas dan wewenang dewan perwakilan rakyat daerah provinsi, kabupaten/kota perlu dilakukan penyesuaian dengan undang-undang yang mengatur pemilihan gubernur, bupati, dan wali kota;" huruf c menyebutkan bahwa "bahwa untuk mengatasi permasalahan sebagaimana dimaksud pada huruf $b$, ketentuan tugas dan wewenang dewan perwakilan rakyat daerah provinsi, kabupaten/kota sebagaimana diatur dalam Undang-Undang Nomor 23 Tahun 2014 tentang Pemerintahan Daerah perlu dilakukan perubahan;" huruf d menyebutkan bahwa "bahwa berdasarkan pertimbangan sebagaimana dimaksud dalam huruf a, huruf $b$, dan huruf c perlu membentuk Undang-Undang tentang Perubahan Kedua atas Undang-Undang Nomor 23 Tahun 2014 tentang Pemerintahan Daerah;".

Banyaknya Kepala Daerah yang terjerat kasus tindak pidana korupsi dalam UU No 9 Tahun 2015, membuat DPRD Provinsi diberikan tugas dan wewenang untuk memilih Gubernur dan Wakil Gubernur dalam hal terjadi kekosongan masa jabatan untuk meneruskan sisa masa jabatan. Begitupun dengan DPRD Kabupaten/Kota dalam Undang-Undang tersebut diberikan tugas dan wewenag untuk memilih bupati dan wakil bupati serta wali kota dan wakil wali kota dalam hal terjadi kekosongan jabatan untuk meneruskan sisa masa jabatan. Sebagaimana UU No 2 Tahun 2015 tentang Penetapan Peraturan Pemerintah Pengganti Undang-Undang tentang Perubahan atas UU No 23 Tahun 2014 tentang Pemerintahan Daerah.
Dalam UU tersebut wakil kepala daerah dipilih secara paket bersamaan dengan calon wakil kepala daerah, perubahan beberapa pasal yang terdapat dalam UU No 9 Tahun 2015 perubahan atas UU No 23 Tahun 2014 menekankan pembagian tugas kepala daerah dan wakil kepala daerah, dan mekanisme pengisian jabatan dalam hal terjadi kekosongan, sehingga dalam menjalakan tugasnya berupaya agar tidak terjadi disharmoni antara kepala daerah dan wakil kepala daerah, agar roda pemerintahan dapat terus berjalan sesuai asas-asas yang telah ditentukan oleh UU.

Namun mekanisme perubahan ini belum mampu sepenuhnya melingkupi kinerja pemerintah daerah yang bebas dari praktik-praktik korupsi apabila, DPRD belum secara maksimal menjalankan tugas dan wewenangnya dalam hal pengawasan, serta mekanisme dalam pemilihan kepala daerah dan wakil kepala daerah dalam hal kekosongan masa jabatan untuk meneruskan sisa masa jabatan.

Padahal, apabila kepala daerah (gubernur, bupati, atau wali kota) berhenti karena meninggal dunia, diberhentikan karena berhalangan tetap, atau diberhentikan berdasarkan putusan pengadilan yang telah memperoleh kekuatan hukum tetap, maka dilakukan pengisian jabatan kepala daerah sesuai dengan ketentuan peraturan perundangundangan mengenai pemilihan kepala daerah, sebagaimana Pasal 76 huruf e UU No 23 Tahun 2014 menyebutkan bahwa "Kepala daerah dan wakil kepala daerah 
dilarang: e. melakukan korupsi, kolusi, dan nepotisme serta menerima uang, barang, dan/atau jasa dari pihak lain yang mempengaruhi keputusan atau tindakan yang akan dilakukan;", kemudian Pasal 78 ayat 2 huruf e menyebutkan "melanggar larangan bagi kepala daerah dan wakil kepala daerah sebagaimana dimaksud dalam Pasal 76 ayat (1), kecuali huruf c, huruf i, dan hurufj;".

Seharusnya, DPRD memaksimalkan tugas dan wewenangnya dalam melaksanakan pengawasan kepada Pemerintah Daerah. Jika penggantian kepala daerah dan wakil kepala daerah dalam rangka mengisi kekosongan jabatan karena kepala daerah sebelumnya telah terbukti melakukan pelanggaran dan memiliki keputusan hukum yang tetap, maka pelaksana tugas atau pengisi jabatan untuk meneruskan masa jabatan haruslah berintegritas dan bukan menambah deretan keterlibatan kasus-kasus korupsi yang dilakukan oleh pejabat-pejabat daerah.

\section{KESIMPULAN}

Desentralisasi yang seharusnya mampu menjadi suatu asas yang baik dalam menjalankan sistem pemerintahan, justru dalam otonomi daerah di Indonesia menjadi salah satu penopang terjadinya pelanggaran-pelanggaran terhadap Undang-Undang.

Kemunculan raja-raja kecil di daerah otonom membuat sebagian orang mampu menguasai akses sumber daya dan konstelasi politik lokal. Sehingga rakyat daerah cenderung pasif terhadap demokrasi karena melulu dijejali oleh berbagai berita tentang korupsi di daerah. Hal ini tidak sejalan dengan apa yang dicita-citakan dari dilaksanakannya otonomi daerah.

Modus-modus bagi tindak pidana korupsi juga semakin menjalar di daerah, jika kita melihat perbandingan data pada pembahasan jurnal ini, trend korupsi menjadi semakin beragam.

Paket perubahan Regulasi hanya sekedar menjadi tambal sulam bagi jalannya pemerintahan daerah.

\section{REFERENSI}

ICW, D. I. (2014). Tren Korupsi Semester 1 Tahun 2014. Jakarta: Indonesia Corruption Watch.

Korupsi, K. P. (2011). Laporan Akhir Tahun 2011. Jakarta: Komisi Pemberantasan Korupsi.

Kustiawan. (2011). Otonomi Daerah dan Desentralisasi Dalam Bingkai Negara Kesatuan Republik Indonesia. Jurnal FISIP Universitas Maritim Raja Ali Haja, 312-323.

Manan, B. (1990). Hubungan Antara Pusat dan Daerah Berdasarkan Azas Desentralisasi Menurut UUD 1945. Bandung: Universitas Padjajaran.

Noor, M. (2012). Memahami Desentralisasi Indonesia. Yogyakarta: Interpena.

Putra, P. B. (2012). Korupsi di Daerah : Salah Jalan Penyelenggaraan Administrasi Daerah. Jurnal Borneo Administrator, 161-179.

Surkati, A. (2012). Otonomi Daerah sebagai Instrumen Pertumbuhan Kesejahteraan dan Peningkatan Antardaerah. Jurnal Mimbar, 39-46. 
Undang-Undang Nomor 23 Tahun 2014 Tentang Pemerintahan Daerah

Undang-Undang Nomor 9 Tahun 2015 Tentang Pemerintahan Daerah Perubahan Atas Undang-Undang Nomor 23 Tahun 2014

Widhi Novianto, E. S. (2015). Telaah IsuIsu Strategis Desentralisasi dan Otonomi Daerah. Jakarta: Pusat Kajian Desentralisasi dan Otonomi Daerah Lembaga Administrasi Negara. 